THE VOICE OF THE SOUTHERN DiAsPORA

\title{
Muddy Waters and the Multi-Layered Influences Associated with the Diffusion of Blues Culture
}

JOHN BYRON STRAIT

Sam Houston State University, U.S.A

\section{KEY WORDS}

Migration

Race

Diaspora

African-American identity Music
ABSTRACT

This paper focuses on the dynamic nature of the Southern Diaspora, the twentieth-century mass migration of African-Americans in the United States from the rural south to the urban north and west. The significant migratory links between the Mississippi Delta and Chicago, Illinois, and the influences it had on the larger diaspora are emphasized. The music of famed blues artist Muddy Waters is used as a lens to demonstrate both the causes and the significant impacts of this diaspora. By exploring the multi-layered circuitry of change associated with the evolution and diffusion of Delta blues music, this paper reveals the transnational and transcultural dimensions of the Southern Diaspora. 
Well, I'm going away to leave; won't be back no more.

I Can't Be Satisfied; Muddy Waters 1948 (Waters 1948).

\section{Introduction}

7 heabove words represent the opening lyrics to a song (I Can't Be Satisfied) recorded for Aristocrat Records in Chicago, Illinois in 1948. The soulful blues song, generally categorized as a Chicago Blues, represents an updated, electrified and more urbanized version of "I Be's Troubled," an acoustic rural blues tune first recorded seven years earlier on the Stovall Plantation, near Clarksdale, Mississippi, in the heart of the Mississippi Delta. The musical transformation which transitioned rural Delta Blues - symbolized by "I Be's Troubled" - into electrified urban blues - represented by "I Can't Be Satisfied" - was just one of the many geographical and cultural outcomes of the most significant internal migration in U.S. history. This twentieth-century mass migration witnessed the relocation of millions of rural southerners to the urban north and west, ultimately changing the very nature of the United States, and indeed the world, in numerous ways. In a comprehensive and thorough study focused on the multiple dimensions of this mass-migration, thehistorian James Gregory referred to this phenomena as the "Southern Diaspora" (Gregory 2005: pp. 11). I adopt Gregory's label in this paper and invoke the term Southern Diaspora as a means to demonstrate the full geographical relevance of this significant migration (Strait 2019: pp. 3).

The life of the composer and vocalist responsible for both "I Be's Troubled" and "I Can't Be Satisfied," McKinley Morganfield, later to be known worldwide as Muddy Waters, essentially paralleled the story he put to song. He was born and raised in the Mississippi Delta and was a long-time resident laborer on the Stovall Plantation, yet shortly after recording "I Be's Troubled" he did indeed pack a suitcase and "go away," leaving the plantation life of his Delta home forever far behind. Like millions of other fellow Delta migrants who participated in the Southern Diaspora, Waters ultimately relocated to Chicago, Illinois, the city Muddy was later referred to as"the biggest city in Mississippi" (Gordon 2002: pp. 67). The musical changes he helped facilitate upon arriving in Chicago both revolutionized and globalized American music, justifying his famous moniker as the "Father of Electric Blues." Moreover, the musical expressions he created, both before and after hisrelocation, ultimately reflected and encouraged social changes that were global in scope and transcended the world of music.

In earlier work, I have utilized blues music and culture as a means to offer a geographically expansive reassessment of the Southern Diaspora, essentially situating it within a much more expansive global network of flows and movements (Strait and Fujimoto-Strait 2017: pp. 4; Strait 2019: pp. 11). My aim here is to use the lens of blues music, as represented by the music of Muddy Waters, to focus directly on how the migration flow from the rural portions of the southern U.S. to the urban north functioned as the essential migratory link driving this global circuitry of flows. In short, this paper explores the complex dynamics associated with the Southern Diaspora and reveals how the music of Muddy Waters is reflective of the root causes, motivations, and impacts of this significant migratory process. This paper contributes to the migration literature in three main ways. First, I explore the larger significance of this diaspora, including a focus on the racially specific implications of both its causes as well as its impacts. Second, I submit Muddy Waters as the musical voice of this diaspora, thus illuminating the important role that migrants themselves may have in terms of narrating their own geographic experiences. Third, by focusing on the geographical and social relevance of musical evolution to this diaspora, and by linking it to an extensive network of cultural movements, this paper addresses the potential transnational impacts of more localized inter-regional migration patterns.

The remainder of this paper is divided into four main sections. The first section provides a brief background to the Southern Diaspora, summarizing how and why the causes and outcomes of this diaspora had particularly significant effects on the African-American population. A second section focuses on the 
important function that musical narration served in terms of diffusing the implications of this diaspora, particularly the role played inglobalizing its effects. The third section of the paper utilizes the life and music of Muddy Waters to emphasize how the specific linkages between the Mississippi Delta and the urban north, particularly Chicago, Illinois, functioned to channel and encourage critical dimensions of this diaspora. The final section introduces discussions and conclusions.

\section{The Great Southern Diaspora and its Impact on African-Americans}

The literature focusingon the Southern Diaspora is extensive, conceptually rich and growing, yet the temporal and demographic framing of this phenomenon has varied considerably. Some scholars have differentiated between two distinct migrations, while others have treated these as different "phases" within a single, more extensive diaspora (Gregory 2005: pp. 23; Strait 2019: pp. 5). Scholars also offer different starting and ending dates, for this broad diaspora, and temporally segment it indifferent ways. Southerners had been relocating to the north and west for centuries, but these migration flows noticeably accelerated during the early part of the 20th century, primarily due to the surging demand for labor required by the urban industries located in these growing regions. This initial migratory phase was originally labeled the "Great Migration," a term most commonly used to reference the large-scale relocations of southern African-Americans to the urban north, a trend that continued to increase through World War I and the early 1920s (Grossman 1989; Lemann 1991; Trotter 1991; Harrison 1992; Sernett 1997; Holly 2000, Strait 2019: pp. 5). The diaspora exhibited a brief interlude during the 1930s when the Great Depression led to a nation-wide decline in job opportunities, an event that placed considerable restrictions on mobility rates among rural populations.

The depression-generated interlude in the diaspora was followed by a second, more significant, phase of migration that began with the onset of World War II, as booming war-time industries provided unprecedented job opportunities available across the northern manufacturing belt and along the west coast. This second phase, often referred to as the Second Great Migration, extended from the early 1940s through the mid-1970s, an era during which African-Americans and whites fled the rural south in droves (Gregory 2009: pp 16). The conclusion of the 1970s marked yet another demographic turn, one generated by global economic transformations that culminated in the deindustrialization of the northern manufacturing belt and the economic emergence of the Sunbelt. By 1980, the combination of these economic processes had altered the relative geography of employment opportunities, leading the southern U.S. to become a major destination for in-migration, rather than a source of outmigration, a demographic shift that initiated the post-diaspora period in the U.S.

The labeling of this migration may lack consistency, and scholars may debate its precise time- frame, but there has been no denying its magnitude. By the time the Southern Diaspora was fully complete, more than 28 million southerners, including at least 20 million whites and 8 million African-Americans, had relocated from the south to places north and west. This momentous geographical process ultimately realigned regional geography, transformed America's religious institutions, restructured its cities, reconfigured its political landscape and was essentially responsible for the development of American popular culture (Gregory 2005; pp. 15). Like most major migrations, the Southern Diaspora was partially a response to regionally varied economic factors, yet both its causes and its impacts stem at least indirectly from its links to the reconstruction of race.

Relocating "up north" did far more for African-American migrants than just enhance employment opportunities, it also offered a means to escape from the brutal system of Jim Crow, a complex socio-political system that has been described as being "much closer to slavery than normal employment conditions" (Lemann 1991: pp. 6). This system, operating as slavery of economics, generally tied millions of rural African-Americans to a sharecropping lifestyle dominated by the labor-intensive needs of cotton agriculture (Powledge 1992; pp. 55). Moreover, 
this system also incorporated a variety of social norms, both formal and informal, that collectively served to deny even the most basic forms of human rights to the labor force it was dependent upon (Cobb 1992; Powledge 1992; Grant 1993).

By the mid-1940s, the combined effect of increasingly abundant jobs in the urban north and the ever-present desire to flee the brutalities of Jim Crow generated an exodus of AfricanAmericans from the rural south. The outcomes of this exodus would have transformative effects on the overall African-American experience, effects that were ultimately manifest worldwide (Griffin 1996; Strait 2019). When the Southern Diaspora was complete, a population that had formerly been mostly southern and rural had become mostly urban and spread throughout the United States. This same population, which had formerly been heavily concentrated within an archaic agricultural economic system, would enter the core of an emergent and rapidly growing manufacturing economy. Perhaps most importantly, African-Americans previously denied access to basic political rights and cultural influence, would gain both.

\section{Narrating and Diffusing the Diaspora via a Global Network}

A major reason the Southern Diaspora was so significant, and perhaps the major reason why it was so impactful for African-Americans, was because it was so thoroughly documented and narrated. This particular migration was written about in newspapers, analyzed by social scientists, memorialized in novels, lampooned by comics, and depicted via music, television, film, radio, and the visual arts (Palmer 1982; Grossman 1989; Griffin 1996; Gregory 2005). Most importantly, these various forms of narration were occurring before, during and after the migration, and not just by observers, but also frequently by migrants themselves. These narratives, some being disseminated literally while the diaspora was unfolding, offer considerable insight as to the motivations for and outcomes of relocation, and reveal how the experiences of migrants related to both (Silvey and Lawson 1999; Lawson 2000). I maintain that blues artists, many of whom were indeed migrants, were responsible for some of the most influential forms of diaspora narration. For one, these musicians were operating within a cultural arena and during a time, whereby whites, both in the United States and elsewhere, where finally willing to openly acknowledge and celebrate African-American-influenced creativity on its own terms (Levine 1977; Floyd 1995; Neal 1999; Gregory 2005: pp.135). Furthermore, these musicians were creating art that both enveloped their rural past and enlivened their new urban experiences, thus providing a vivid soundtrack for the overall diaspora experience (Strait 2019: pp. 21). Perhaps most importantly, the diasporafueled music was being disseminated through a globalizing network of diffusional pathways, ensuring that the causes, impacts, and outcomes of the diaspora would become visible to the world.

Strait and Fujimoto-Strait (2017) utilized a panoramic perspective to demonstrate the transcultural and global nature of what they referred to as "Delta Blues culture," a cultural milieu that includes the blues music from the Mississippi Delta, as well as the cultural and geographical dynamics associated with it. They describe the evolution of this transcultural milieu as being a response to the emergence of cultural influences that diffused among four continents, multiple nation-states, and the Pacific Islands of Hawaii. Figure 1 depicts the main diffusional pathways comprising this multilayered network of cultural flows they identified, with the migration flow generated by the Southern Diaspora represented by Stream 4.Prior to it flowing to the urban north and west, the musical culture that evolved in the U.S. South, particularly within the Mississippi Delta, already represented a uniquely syncretic phenomenon. Once this transcultural musical form diffused north and west (Stream 4), in fact precisely because it diffused, it further transformed into an urban form that ultimately spread world-wide (Stream 5). The outcomes of this musical evolution and its diffusion were significant in numerous ways and were to eventually return "home" to the U.S. via the British Invasion (Stream 6). 
Figure 1. Pathways of Movement Associated with the Diffusion of Blues Culture.

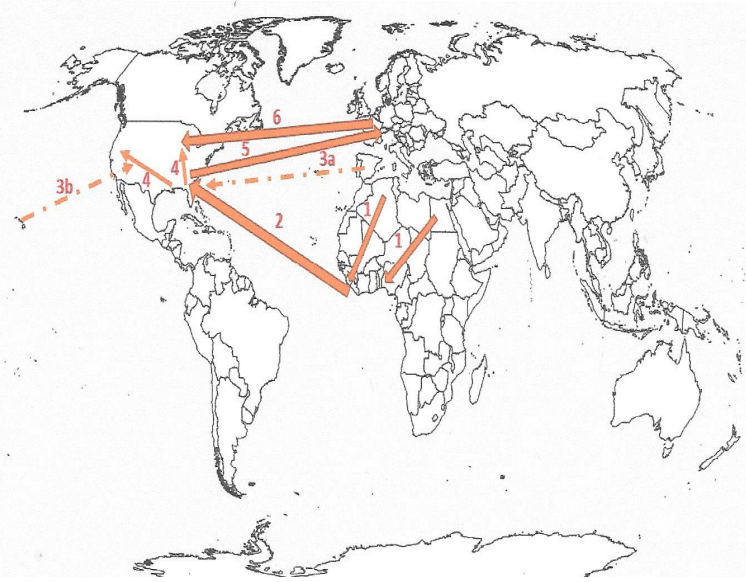

Stream 1:Arab and Berber musical culture diffuse from North Africa and the Middle East into portions of West Africa. These musical influences syncretically combine with West African musical traditions.

Stream 2: Elements of West African musical culture diffuse to theSouthern United States via the Atlantic Slave trade; eventually merging with European musical traditions and evolving into blues music.

Streams 3a \& 3b: Musical influences from the Iberian Peninsula and the Hawaiian islands diffuse to the Southern U.S. via the guitar traditions of open tunings and slide guitar, contributing to the development of a distinct subgenre of blues (Delta blues) in the Mississippi Delta.

Stream 4: Blues music diffuses to the urban north and west via the Southern Diaspora. A uniquely influential genre of urban blues develops in Chicago that was directly influenced by Delta blues.

Stream 5: Blues diffuse to Europe via record sales, postwar radio and live performances. This music is highly received in the United Kingdom, particularly within London, Liverpool, and Newcastle.

Stream 6: Blues "returns" to the United States via blues-influenced rock ' $n$ ' roll. The British Invasion (e.g., Beatles, Rolling Stones, Animals, Yardbirds, Led Zeppelin) re-exposes America to music from the Delta.

It should be noted that it was not just music that was being transferred along with the network of flows depicted in Figure 1. The music that diffused along these various pathways was an exceptionally expressive and impressionable form of social art, thus it also functioned as a conduit for the narration of other forms of cultural influence (Gregory 2005: pp. 135; Strait 2012: pp. 201). For example, the rest of the United States and the world were not just consuming the music southern blues artists had brought north and west, they were also being introduced to changing fashions, social styles, and different languages. Most importantly, by consuming these inter-connected cultural forms, the world was also exposed to and influenced by a new outlook and world view that evolved as the diaspora progressed.

\section{Muddy Waters as an Agent of Change}

As a migrant and musician, the story of Muddy Waters is central to the unfolding dynamics of the Southern Diaspora, in terms of both the motivations that drove the process, and its spatial and cultural impacts. The geographical biography of this Mississippi-born bluesman, and the spatial dimensions of his music, are utilized here to demonstrate the following: 1) the vital role that Water's birthplace, the Mississippi Delta, served as a geographical incubator that spawned a uniquely transcultural musical form whose influences were made increasingly more significant as the diaspora unfolded; 2) the significant degree to which Muddy's life and music were emblematic of the causal factors that fueled the mass migration, 3) the impacts that the Delta's blues culture had on popular culture as it diffused globally, specifically in regards to musical evolution, and 4) the critical role this music served in terms of mediating the major cultural changes that manifest as the diaspora unfolded, including its influence on the evolution of African-American identity.

\section{The Birth Place of a Transcultural Blues Culture}

The Mississippi Delta, also known as the YazooMississippi Delta, is a geographically and culturally distinctive section in the northwestern portion of the U.S. state of Mississippi. If one were to define this region strictly in terms of 
physical and cultural geography, as opposed to using official state political boundaries, it also encompasses portions of Arkansas and Louisiana. Geomorphically, the region is not a true delta; rather it is an alluvial floodplain, the Mississippi portion of which lies between the Mississippi and Yazoo rivers (Figure 2). The region has frequently been referred to as "The Most Southern Place on Earth," a reference to its unique social, cultural, racial, economic and political history, rather than its actual absolute location (Cobb 1992; Willis 2000; Woodruff 2003; Wilson 2004; Ferris and Hinson 2009). The region is also widely known for its vibrant musical heritage, particularly in regards to the origins of Blues, Rock ' $n$ " Roll and Gospel, thus explaining its common reference as both the "land where the blues began," and the "birthplace of American music" (Lomax 2002). Blues heritage as a form of tourism is vividly evident on the landscape of the Delta, as a large number of towns, cities, and/or sites across the region making some claim linking it to the "birthplace of the blues." Assertions of tourism brochures aside, it is obviously impossible to definitively determine where any musical form was actually "born." However, there can be no denying that the music from the Delta, and the many musicians responsible for its creation, have been especially influential. Few Delta musicians, in fact, few musicians from anywhere and/or from any genre, have had as much impact on the world of music as Muddy Waters. These substantial impacts can be partially explained by his talent and overwhelming drive to succeed, traits that he certainly possessed in abundance, yet his musical trajectory was also influenced by and benefited from the cultural context unique to his place of birth.
Figure 2. The Mississippi Delta (Map by author)

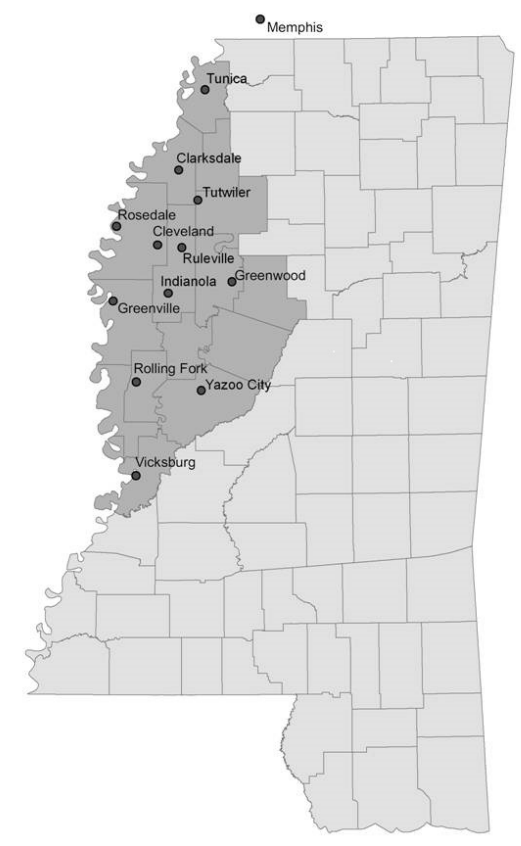

Muddy Waters was born around 1913 in the southern part of the Delta, in Issaquena County, in a community known as Jug's Corner. While he was very young, he moved eighty miles north to the Stovall Plantation, in Coahoma County, Mississippi. It was this community, located just outside the city of Clarksdale, that he would always to refer to as home (Gordon 2002: pp. 3).A historical marker now sits at the former site of his boyhood plantation home, but the musical legacy of Stovall Plantation and Coahoma County predates the presence of the community's most famous resident son. In 1901 Harvard archeologist Charles Peabody was directing excavations in this same immediate area in efforts to uncover Native American remains, endeavors that ultimately led to the first academic publication documenting the Delta's unique music. This came to fruition when Peabody witnessed and started noting the distinctive music his local African-American work teams used to provide rhythm and cadence for their laborious tasks, as well as the unusual songs they shared during moments of leisure. His paper entitled "Notes on Negro Music" offered "suggestions for the future study in musical classification," and was ultimately published in the Journal of American Folklore (Peabody 1903; pp. 148). In this work, Peabody describes 
musical strains of what are now recognized as key ingredients for Delta Blues. This included the interval use of "three chords" on guitar as means to echo a singing voice, monotonous yet simple alterations in pitch, lyrical themes focusing on tales of "hard luck" and "love," and unusual rhythms and dissonances now referred to as "blues" notes (Peabody 1903; pp. 152; Gioia 2008; pp. 21).

In hindsight, the most geographically relevant observation Peabody shared in this paper involved his descriptions of late-night musical performances by one particular "old negro" singer. The experience of witnessing this man sing made such an impression on Peabody that he described the vocal delivery in vivid detail, using characterizations that would later be used to delineate "field hollers." This older AfricanAmerican laborer, whose song-style Peabody would sum up as being "monotonous but weird," was known to be from the same plantation that Muddy Waters was to later call home, and where he was first recorded - the Stovall Plantation (Peabody 1903; pp. 152; Lomax 2002). Given that the "Father of Urban Blues "grew up in the same locale as the anonymous singer Peabody encountered, we can probably assume they were exposed to similar cultural influences. Alan Lomax, who along with colleague John Work, was responsible for first recording Waters on Stovall in 1941, engaged in numerous field recordings across the Delta during the same time period, including several within Coahoma County. The two men encountered various examples of "field" or "work hollers" during their field endeavors and after hearing Waters play for the first time, classified the blues man's singing style as falling within this same vocal tradition. Lomax consistently interpreted their numerous encounters with this style of music, including their recordings with Muddy Waters, as evidence of the widespread African musical influence evident within the blues genre (Lomax 2002).

Subsequent research on cultural linkages has demonstrated overwhelming evidence that blues music cannot be solely defined by African customs and musical traditions alone, evidence that can be directly confirmed by considering the unique influences that Muddy Waters had on the musical world.
Musicologist and blues writer Samuel Charters, following decades of field-work in Africa, verified a host of African influences, yet concluded that "American blues" was essentially a "new world" cultural product (Charters 1981). A cartographic interpretation of the cultural flows identified by Strait and Fujimoto-Strait (2017, pp. 5) confirms the Charter's hypothesis and highlights the transcultural roots behind the musical influences of Muddy Waters (Figure 1). The unique musical form that manifest or that was "born," in the Delta (Delta Blues) was certainly African-rooted, yet was also heavily germinated by multi-layered cultural influences from a number of other places (Figure 1: Streams $1,2,3 \mathrm{a}$ and $3 \mathrm{~b}$ ). Case in point, Muddy Waters did indeed vocalize his Delta blues music using a "field holler" song-style that combined the practice of melisma, a vocal tradition linked to Islamic calls to prayer common throughout North Africa and the Middle East, with rhythmbased linguistic heritages of West Africa (Streams $1 \& 2$, respectively). Yet his signature style of combining the slide guitar (Stream 3a) with the tradition of using open-tunings (Stream $3 b$ ), what he referred to as "Spanish tuning," represents Hawaiian, European and Mediterranean influences. In short, while the history of the Mississippi Delta ensured that its cultural tone would be heavily impacted by the maintenance of African musical traditions, the linkages this specific region had with a diverse collection of other places is what led it to "give birth" to something uniquely influential.

\section{Causal Factors Driving the Diaspora}

Muddy Water's geographical biography is directly and/or indirectly linked to a number of factors responsible for encouraging mass migration from the Delta. Accordingly, his life exemplifies the larger meanings of the Southern Diaspora. In the fall of 1944 the complete mechanization of cotton agriculture, a technological process that transformed the southern United States and the world, was launched in Coahoma County (Holley 2000). This process commenced on the Hopson Plantation, a cotton plantation located a mere seven miles from Muddy's home at Stovall, when International Harvester introduced the first 
commercially successful mechanical cotton picker. With the successful introduction of this machine, the Mississippi Delta became the first region in the world where commercial acreages of cotton were grown and harvested completely by mechanical methods. In time, this technological shift almost totally eliminated the demand for labor throughout the cotton belt, which in turn effectively made the sharecropping system extinct. Accordingly, agricultural mechanization ultimately made migration to the northern and western cities a viable alternative, if not a required alternative, for southern African-Americans whose traditional livelihoods were terminated. It is worth noting that the successful introduction of this particular machine was the culmination of a larger technological process, which also included the increased use of trucks, herbicides, mechanical cultivators, and tractors. In fact, prior to migrating to Chicago, Muddy Waters himself benefited from and was a participant in an early stage of this technological revolution. When he was first recorded by Alan Lomax and John Work in 1941, the future Father of Electric Blues was then serving as the main tractor driver on the Stovall Plantation.

The mechanical cotton picker eventually had profound sociological impacts that extended far beyond the world of agriculture, or even economics. Holley (2000) has thoroughly discussed the more complex spillover effects that agricultural mechanization had in terms of regional convergence, civil rights, and social and political change. The plantation system in the south was essentially dependent upon access to a large labor force that was poor, ignorant, controllable, and lacking in overall economic opportunity. According to Holley, the region could not transition from the operational and intellectual defense of this system,without the dramatic technological breakthrough provided by the mechanical cotton picker and the agricultural transformation that followed(Holley 2000). The proliferation of the mechanical cotton picker was an undeniable factor linked to the Southern Diaspora, yet Holley also offered compelling empirical evidence that agricultural mechanization was as much a response to outmigration from the south as it was a cause of migration. In short, cotton planters may have in actuality been forced to implement mechanization because their traditional labor force was rapidly disappearing (to be precise, they were moving north and west).

Holley's evidence regarding the nature of the causal links between outmigration and mechanization suggests that the primary motivation fueling the Southern Diaspora was most likely the strong desire among AfricanAmericans to flee the brutally exploitive system of Jim Crow. The structural and discriminatory inequities that defined this system - arbitrarily low wages, inferior or non-existent schooling, severe restrictions regarding mobility and/or the realization of political and economic opportunities - were arguably more deeply ensconced in Muddy Water's Delta home than anywhere else in the United States. (Woodruff 2003). Consequently, frustrations with and opposition to this system were themes consistently expressed via the dissemination of Delta Blues, particularly within Muddy's blues music. Muddy combined themes of mistreatment and movement in his first two recordings for Lomax and Work on Stovall Plantation in 1941, vividly sharing desires that resembled a spiritual calling to leave this system:

"Well, if I feel tomorrow like I feel today, I'm going to pack my suitcase and make my getaway." "Lord I'm troubled, I'm all worried in mind." - I Be's Troubled (Lomax et al. 1941a)

Well, I'm leaving this morning, if I have to ride the blinds. I feel mistreated girl, you know now, I don't mind dying. - Country Blues (Lomax et al. 1941b)

Evoking the spiritual idea of earthly "troubles," a theme very familiar to AfricanAmericans southerners immersed within traditions of Christianity, "I Be's Troubled" expressed the deeply felt sorrows shared by millions of potential migrants. The singer offers geographical mobility as a solution to these troubles, and in "Country Blues" even demonstrates a specific form of mobility as a potential cure, submitting the "blinds" (train) as a mechanism to mitigate this mistreatment. Here,we are witnessing the psychological emphasis on movement as a form of cultural 
freedom, a theme frequently used, both metaphorically and literally, within various African-American musical traditions. The songs express the dream of realizing this form of freedom by leaving the Delta and its troubles behind, a dream Muddy Waters shared with many of his listeners.

When he re-recorded this same song in Chicago in 1948 as "I Can't Be Satisfied," Muddy altered his geographical perspective by suggesting he had already left the south, clearly demonstrating an awareness that his home was now the urban north. However, he still expresses themes of frustration, exploitation, and loss, and offers mobility or movement as a coping mechanism to alleviate these frustrations: Mobility is interpreted here in both its literal and figurative senses; movement away from the geographic source of mistreatment, as well as the figurative movement of solidarity required to change collective social conditions:

"Going back down south, child; don't you want to go? ... Well, babe, I just can't be satisfied, and I just can't keep from crying." - I Can't Be Satisfied (Waters 1948)

This song's refrain, 'I've never been satisfied," echoes a folk song connected to a common ring shouts game popular among adolescents in the Delta during the early part of the 20th century (Rutkoff and Scott 2005). For example, a version of this song, entitled "Satisfied" and credited to Florence Stamp and a group of anonymous girls, was recorded by Alan Lomax in Coahoma County, outside a church in Friars Point, in 1942 (Lomax 2002). This ring shouts game places participants in a circle, where they chant and clap in syncopated fashion, and are encouraged to switch to a new dance partner when they become dissatisfied with a former one. In a similar fashion, Muddy's blues music, born from the same cultural and geographical environment, motivated his listeners to cure their dissatisfactions by leaving their troubles behind and pursuing a better life elsewhere. Many southern African-Americans from the rural south did indeed follow the same paths as Muddy Waters and migrated to the urban north and west. In an interesting twist of irony, some of these migrants would eventually find work in factories in the urban north that manufactured the mechanical cotton picker, the very implement largely responsible for terminating the traditional livelihood available in their former rural southern home.

\section{Musical Evolution and the Globalization of Blues Culture}

Muddy Waters left the Mississippi Delta for Chicago in 1943, and shortly after arriving became an influential entertainment fixture in the clubs, bars, and taverns located throughout the city's famed South Side. The blues music he created in his new urban home remained Delta rooted, both thematically and sonically, yet reflected changes manifest with the diaspora. This new urban environment, with its crowded and noisy nocturnal atmosphere, placed an emphasis on a strong voice and required amplified instrumentation. Muddy contributed to the transition of Delta Blues into Urban Blues (or Chicago Blues) by beefing up the rhythm sections of his band, and by doing so reestablished what was to become the traditional musical arrangement - two guitars, harmonica, piano, bass, and drums. This transition was encouraged by his band's reliance on a technological implement that in many ways represents the blues man's answer to the mechanical cotton-picker; the electric guitar. In time, this new instrument - the "rhythm guitar" replaced the piano as the primary feature of rhythm sections, a shift that enhanced the musical textures and grooves, and enabled blues sounds to grow louder, and become more rhythmically penetrating (Gioia 2008; pp: 221).

The uniquely raw, electric, and sonically intense urban music Muddy formulated in Chicago became increasingly influential as it continued to evolve geographically, musically, and culturally. After taking root in northern cities, this Delta-born music eventually diffused to a worldwide audience, a geographical process stimulated by advances in post-war radio, overseas record sales and eventually via performances by blues musicians themselves. Its immediate effects, those functioning as a collective springboard for its broader influences on the world, were realized once this urban music diffused to Europe. The music was highly 
received in the United Kingdom, especially after youth in London, Liverpool and Newcastle were directly exposed to live performances by Deltaborn blues artists (stream 5). For example, the sound and the very nature of British music was totally transformed following Muddy Water's amplified and shockingly influential performance at the 1958 Leed's Festival (Gordon 2002; Gioia 2008; Strait and Fujimoto-Strait 2017). It was his music, and other Delta-rooted blues from Chicago, that directly influenced a host of British bands and artists, such as the Rolling Stones, Eric Clapton, the Animals, the Yardbirds, and Led Zeppelin, groups that ultimately diffused their own energetic blues-influenced genre of rock music back to the United States (Figure 1; stream 6). The comments of Muddy's contemporary bluesmen John Lee Hooker, also born and raised in the Delta, sums up the cultural impacts this socalled "British Invasion" had in the United States:

\footnotetext{
"...the groups from England really started the blues rolling and getting bigger among the kids - the white kids. At one time, fifteen years back, the blues were just among the blacks - the old black people. And this uprise started in England by the Beatles, Animals, Rolling Stones, it started everybody digging the blues" John Lee Hooker (Hall 1998)
}

The impact of Muddy Water's music, and the Delta, on this back-and-forth flow of blues culture (Figure 1; streams $5 \& 6$ ) is best exemplified by the trajectory of The Rolling Stones. The group took their name from one of Water's signature tunes (Rolling Stone), and in 1965 they traveled directly from London to Chicago to record in the exact same South Side studio where Muddy himself recorded his early hits (Strait and Fujimoto-Strait 2017). It was in this studio, Chess Records, that they recorded their first number one hit, a song now considered one of the greatest Rock'N'Roll songs of all time; "(I Can't Get No) Satisfaction." This tune expressed the alienation, frustrations, and rebelliousness exhibited by youth worldwide, thus vividly capturing the counter-cultural spirit of the time. This influential Rock'N'Roll song was inspired both thematically and musically by Muddy's Chicago blues song "Can't Be Satisfied," thus its roots extend back to the Mississippi
Delta, the cultural hearth where its musical antecedents evolved.

\section{The Spatial and Social Evolution of African-American Identity}

The counter-cultural appeal of Muddy's Deltarooted Chicago Blues was not limited to disaffected white youth, nor did its impacts only manifest via musical progression. The increased dissemination of this music also played a profound role in narrating the significant changes in black consciousness that occurred as the diaspora progressed. In fact, the same boisterous celebrations of cultural freedom that motivated the diaspora, musical expressions that represent both causes and effects of massmigration, is exactly what attracted so many rebellious whites on both sides of the Atlantic to the music of Muddy Waters. For instance, a major distinction between the rural identity traditionally shared among African-Americans across the plantation south, and the new AfricanAmerican identity that developed as the diaspora progressed, was the open expression of masculinity common to the urban north. The urban music Muddy produced in Chicago, such as his hits "Hoochie Coochie Man" and "Mannish Boy," openly contested and flaunted the oppressive social constraints ensconced in his former rural home, constraints that severely curtailed any expressions of masculinity:

\footnotetext{
"The gypsy woman told my mother before I was born, I got a boy-child's comin,' He's gonna be a son-of-a-gun, He's gonna make pretty women's, Jump and shout, Then the world gonna know, What this all about." - I'm Your Hoochie Coochie Man (Dixon and Chess, 1954)

"I'm a man; Spell, M. A. chile, N. That'll well within' man' No B. O. child Y; That mean mannish Boy; I'm a man; I'm a full grown man... I'm a natural born lover's man....I'm a man, child; I'm a rollin' stone... I'm the greatest man alive" - Mannish Boy (Waters 1955)
}

These defiant expressions of self-confidence were certainly popular among rebellious white youth, but they evoked significantly deeper meanings to a southern African-American population coping with the oppressive system of 
Jim Crow. Muddy offers repeated embellishments regarding the extraordinary nature of his birth and boisterously celebrated his manhood, thus providing vicarious motivation to a fellow African American population that aspired to leave a social system that effectively dehumanized them. Moreover, by openly asserting his sexual prowess in his music, something the restrictive social hierarchy of Jim Crow would certainly never allow, Muddy was doing more than simply bragging about tawdry encounters. His musical narration was sharing and celebrating with his AfricanAmerican listeners, many of whom were former migrants, the confirmation that these social constraints were tumbling down.

Urban blues and the counter-cultural narratives it invoked, did not cease diffusing once they took root in Chicago. The festive celebration of newly realized cultural freedoms evident with Muddy's Chicago blues, such as the freedoms of social and spatial mobility and expressive boasts of "manhood," were increasingly embraced by a broader audience as they diffused globally. In I'm Your Hootchie Coochie Man the bluesman presciently and explicitly acknowledges this diffusional effect"the world gonna know, What this all about" (Dixon and Chess 1954).The most vivid example of this pertains to the vigorous statement of "manhood" offered in his song Mannish Boy. In this song the bluesman emphatically negates any questions regarding African-American manhood, emphatically challenging the traditional social norms customary to his place of birth by directly spelling out "I'm a Man, spelled M-A-N....No B-OY." The deeper meanings behind his lyrical dissent later became more formally evident with the symbolic use of "I AM a MAN" as a slogan during the 1968 Memphis, Tennessee sanitation strike, a protest whereby Martin Luther King, Jr. expanded the Civil Rights Movement by calling for a broader focus on human rights (Estes 2005; Honey 2007). Muddy's boisterous expression of human dignity has more recently proved to be as temporally and globally resonant as his music, and as transcultural, when it reemerged as a galvanizing symbol throughout North Africa and the Middle East during the Arab Spring political uprisings (Friedman 2011).

\section{Discussions and Concluding Remarks}

In his autobiography, the Harlem Renaissance poet Langston Hughes offered insight on the impact of art on the African-African experience by stating; "the ordinary Negro hadn't heard of the Harlem Renaissance. And if they had, it hadn't raised their wages any." (Hughes 1993; pp. 228). The same is not true with the musical art that evolved during the Southern Diaspora, a migratory process whose effects were widely disseminated via song and which ultimately did far more than just raise wages. This work explores the far-reaching global impacts of the 20th-century mass migration of AfricanAmericans from the rural south to the urban north and west and demonstrates the critical role that Delta-born Chicago blues, specifically the blues music of Muddy Waters, played in terms of narrating this diaspora. This diaspora unfolded over multiple decades, and entailed the migratory flow of millions of people from several different places of origin, to numerous destinations. Moreover, this geographic phenomenon was widely documented in a variety of ways, including by musical voices across multiple genres, none of which should be marginalized or overlooked. This research specifically focuses on the global significance of this diaspora by revealing how Muddy Water's music served to motivate both its causes, and its impacts, both within the United States and across the world. Thus, this work contributed to a growing literature that recognizes migrants themselves as creative subjects of change who reinterpret the significant developments of their own movements, as well as the collective movements of others (Lawson 2000; Toynbee and Dueck 2011; Escobar 2012; Clark 2014).

This research directly contributes to the larger body of work that emphasizes the significance of local contexts, and local cultural practices, to larger diasporic processes that operate at a global scale. It is clear that the Southern Diaspora discussed in this paper represents a single link in a larger and more complex circuitry of flows involving the movement of people and culture over space. The global resonance of Muddy Water's music demonstrates that the migratory connection 
between the Mississippi Delta and Chicago, Illinois functioned as a crucial link that channeled significant implications of this extensive circuitry of cultural exchange. In his book, The Most Southern Place on Earth, historian James Cobb (1992) characterized the Mississippi Delta as a region that exhibited "close and consistent interaction" with a host of prevailing national and global forces. For instance, the transformative effects of the mechanization of cotton agriculture were first instigated in the Delta, but represent local responses to global economic forces. In time, the singular event that transpired near Muddy's boyhood home, the introduction of the mechanical cotton picker, ushered in a broad array of social, political and economic changes that manifest far beyond Coahoma County, Mississippi. The underlying factor that initiated these changes, the decision by Delta planters to implement mechanization, was the realization that so many African-American laborers had heeded the musical call of Muddy Waters and made a "getaway" to the urban north. The transcultural music that encouraged and motivated this mass-migration, itself a result of multiple cultural flows from a variety of sources, was just as globally expansive as the economic forces to which migrants were responding. In short, by demonstrating the complex spatial dynamics linked to both the Delta's innovative agricultural economy and its evolving blues culture, this paper confirms that Cobb's views have a geographical parallel; the unique significance of the Mississippi Delta and the blues music to which it gave birth are due to the region's connections to a variety of other places.

Muddy Water's life may be most directly linked to the Mississippi Delta and Chicago,
Illinois, but the impacts his music engendered, much like the music itself, were truly transcultural and transnational in scope. The diffusion of his Delta-born music to the urban north fueled a network of cultural exchanges between the U.S. and the rest of the world that essentially reshaped popular culture. The musical outcome of these cultural transformations includes the numerous musical progeny of the Delta blues - such Rock' N' Roll, Rhythm \& Blues, Soul, Country, and Rap. Muddy himself emphatically identified the musical genetics via song; "Well the blues had a baby and they named the baby Rock \& Roll" (Waters and McGhee 1977). Yet in this paper, I offer Muddy Waters as the voice of the Southern Diaspora because the dissemination of his music ensured that millions of ordinary people, both AfricanAmerican and white, were exposed to more than just newly urbanized music. Blues artists that boisterously sang about their own migratory motivations and experiences were not just entertainers; they were mediating the deeper meanings of the diaspora for African-Americans everywhere. By asserting the natural freedom to pursue better economic and social opportunities in the north and west, far removed from the confines of the Jim Crow south, diaspora participants were responsible for giving birth to a collective consciousness that reconfigured African-American identity and encouraged the modern Civil Rights Movement. This research confirms that the counter-cultural narratives evident in Muddy Water's Chicago Blues, including the boisterous celebration of "manhood" that was shared worldwide, were providing agency for the interconnected dynamics driving these processes. 


\section{References}

Charter, S. (1981). The Roots of the Blues: An African Search. East York, Ontario: Hushion House.

Clark, M. K. (2014). "The role of New and social media in Tanzanian Hip-Hop Production." Cahiers D'etudes Africaines. 2016 (4): 1115-1136.

Cobb, J. (1992). The Most Southern Place on Earth: The Mississippi Delta and the Roots of Regional Identity. New York: Oxford University Press.

Davis, A. (2011). Blues Legacies and Black Feminism: Gertrude "Ma" Rainey, Bessie Smith, and Billie Holiday. New York: Vintage Books.

Dixon, W. Y Chess, L. (1954). Hoochie Coochie Man. Chicago, Illinois: Chess Records.

Escobar, A. (2012). Encountering Development: The Making and Unmaking of the Third World. Princeton, NJ: Princeton University Press.

Estes S. (2005). I Am a Man: Race, Manhood, and the Civil Rights Movement. Chapel Hill, NC: The University of North Carolina Press.

Ferris, W. R. y Hinson, G. (2009). The New Encyclopedia of Southern Culture. Vol. 14: Folklife. University of North Carolina Press.

Floyd, Jr. S. (1995). The Power of Black Music: Interpreting Its History from Africa to the United States. Oxford: Oxford University Press.

Friedman, T. (2011). "I Am a Man." New York Times, 14 May, A10.

Gioia, T. (2008). Delta Blues: The Life and Times of the Mississippi Masters Who Revolutionized American Music. New York: WW Norton \& Company.

Gordon, R. (2002). Can't Be Satisfied: The Life and Times of Muddy Waters. New York: Little, Brown.

Grant, D. (1993). The Way It Was in the South: The Black Experience in Georgia. New York: Carol Publishing Group.

Gregory, J. N. (1995). The southern diaspora and the urban dispossessed: Demonstrating the Census Public Use Microdata sample. Journal of American History, 82 (1), 111-134.

(2005). The Southern Diaspora: How the Great Migrations of Black and White Southerners Transformed America. Chapel Hill : University of North Carolina Press.

(2009). The second great migration: A historical overview. In: J.W. Trotter, Jr. y K.L. Kusmer (eds.), African-American History: The Dynamics of Race, Class and Gender since World War II (pp. 19-38, Ch. 1). Chicago: University of Chicago Press.

Griffin, F. J. (1996). Who Set You Flowin? New York: Oxford University Press.

Grossman, J. (1989). Land of Hope: Chicago, Black Southerners and the Great Migration. Chicago, Illinois: University of Chicago Press.

Hall, P. (1998). Cities in Civilization. New York: Pantheon Books.

Harrison, A. (1992). Black Exodus: The Great Migration from the American South. The University Press of Mississippi.

Holley, D. (2000). The Second Great Emancipation: The Mechanical Cotton Picker, Black Migration, and How They Shaped the Modern South. Fayetteville, Arkansas: University of Arkansas Press.

Honey, M. K. (2007). Going Down Jericho Road: The Memphis Strike, Martin Luther King's Last Campaign. New York: W. W. Norton and Company.

Hughes, L. (1993). The Big Sea: An Autobiography. New York: Hill and Wang.

Jing, P. J. Y Monteith, S. (2004). Gender and the Civil Rights Movement. New Brunswick, New Jersey: Rutgers University Press.

Lawson, V. A. (2000). Arguments within geographies of movement: The theoretical potential of migrants' stories. Progress in Human Geography, 24 (2), 173-189.

Lemann, N. (1991). The Promised Land: The Great Black Migration: and How it Changed America. New York: Vintage Books.

Levine, L. (1977). Black Culture, Black Consciousness: Afro-American Folk Thought from Slavery to Freedom. New York: Oxford University Press. 
Lomax, A. (2002). The Land Where the Blues Began. New York: The New Press.

Works, J. W., y Waters, M. (1941a). I Be's Troubled. Stovall, Mississippi: Library of Congress.

Works, J. W., y Waters, M. (1941b). Country Blues. Stovall, Mississippi: Library of Congress.

Neal, M. (1999). What the Music Said. London: Routledge.

Peabody, C. (1903). Notes on Negro music. The Journal of American Folklore 16 (62), 148-152.

Palmer, R. (1982). Deep Blues: A Musical and Cultural History, from the Mississippi Delta to Chicago's South Side, to the World. New York: Penguin Books.

Powledge, F. (1992). Review: The great migration. Transactions 55, 74-82.

Rutkoff, P. and Scott, W. (2005). Preaching the blues: The Mississippi Delta of Muddy Waters. The Kenyon Review 27 (2), 129-239.

Sernett, M. (1997). Bound For the Promised Land: African American Religion and the Great Migration. Durham, North Carolina: Duke University Press.

Silvey, R. y Lawson, V. (1999). Placing the Migrant. Annals of the Association of American Geographers 89 (1), 121-132.

Strait, J.B. (2012). Experiencing blues at the crossroads: A place-based method for teaching the geography of blues culture. Journal of Geography 111 (5), 194-209.

(2019). Here, there, and back again: The Southern Diaspora and the Transcultural Music of Muddy Waters. Diaspora (forthcoming).

Strait, J. B. y Fujimoto-Strait, A. R. (2017). The impact of multi-layered diffusionary processes on musical evolution: The global nature, and Hawaiian, Spanish, and African roots of Delta blues culture. European Scientific Journal, October 2017/Special Edition, 257-276.

Toynbee, J, y Dueck, B. (2011). Migrating Music. London and New York: Routledge University Press.

Trotter, J. W. (1991). The Great Migration in Historical Perspective. Bloomington Indiana: Indiana University Press.

Waters, M. (Morganfield, M.). (1948). I Can’t Be Satisfied. Chicago, Illinois: Aristocrat Records.

(1955). Mannish Boy. Chicago, Illinois: Chess Records.

Waters, M. (Morganfield, M.) y McGhee, B. (1977). Blues Had a Baby and They Named it Rock' N' Roll, pt. 2. Chicago, Illinois: Blue Sky Records.

Willis, J. C. (2000). Forgotten Time: The Yazoo-Mississippi Delta after the Civil War, Charlottesville: University of Virginia Press.

Wilson, C. R. (2004). Mississippi Delta. Southern Spaces, 4 April 2004. http://southernspaces.org/2004/mississippi-delta

Woodruff, N. E. (2003). American Congo: The African-American Freedom Struggle in the Delta. Boston, MA: Harvard University Press 